\title{
Impact of diets with different proportions of linseed and sunflower oils on the growth, liver histology, immunological and chemical blood parameters, and proximate composition of pikeperch Sander lucioperca (L.)
}

\author{
Agata Kowalska $\cdot$ Zdzisław Zakęś $\cdot$ Andrzej Krzysztof Siwicki • \\ Barbara Jankowska • Sylwia Jarmołowicz • Krystyna Demska-Zakęś \\ Received: 11 February 2011/Accepted: 18 May 2011/Published online: 9 June 2011 \\ (C) The Author(s) 2011. This article is published with open access at Springerlink.com
}

\begin{abstract}
The aim of the study was to determine the impact of applying different proportions of linseed (LO) and sunflower (SFO) oils in pikeperch diets on growth, histological changes in the liver, immunological and blood chemical parameters. The fish were fed isoenergetic and isoprotein feeds containing SFO (group 100SFO) or LO (group 100LO) in quantities of $67 \mathrm{~g} \mathrm{~kg} / \mathrm{feed}$, and a mixture of oils: $47 \mathrm{~g} \mathrm{SFO}$ and $20 \mathrm{~g} \mathrm{LO} \mathrm{kg/feed} \mathrm{(group} \mathrm{70SFO/30LO)} \mathrm{and} 20 \mathrm{~g} \mathrm{SFO}$ and $47 \mathrm{~g} \mathrm{LO} \mathrm{kg/feed} \mathrm{(group} \mathrm{30SFO/70LO).} \mathrm{Dietary}$ ratios of polyunsaturated fatty acids from the $n-3$ and $\mathrm{n}-6$ series (n3/n6 index) were 0.36-2.15. Pikeperch were reared for 56 days in three replicates for each
\end{abstract}

A. Kowalska ( $\square)$. Z. Zakęś · S. Jarmołowicz Department of Aquaculture, Stanisław Sakowicz Inland Fisheries Institute, Oczapowskiego 10, 10-719 Olsztyn, Poland

e-mail: agatakow@infish.com.pl

\section{A. K. Siwicki}

Department of Fish Pathology and Immunology, Stanisław Sakowicz Inland Fisheries Institute,

Oczapowskiego 10, 10-719 Olsztyn, Poland

B. Jankowska

Department of Meat Technology and Chemistry, Faculty of Food Science, University of Warmia and Mazury, Pl. Cieszyński 1, 10-718 Olsztyn, Poland

K. Demska-Zakęś

Department of Ichthyology, Faculty of Environmental Protection and Fisheries, University of Warmia and Mazury, Oczapowskiego 5, 10-718 Olsztyn, Poland dietary treatment. Various dietary oils and ratios of n3/n6 did not impact fish growth, feed conversion ratio, viscerosomatic and hepatosomatic index, and size of the hepatocytes. Feeding the fish high quantities of LO and SO oils (groups 100LO and 100SFO) reduced the immunological response of the phagocytes and lymphocytes in the fish. Moreover, this resulted in significant differences among groups in the quantity of linolenic and linoleic acid in whole fish bodies, viscera, fillets, and livers. Various quantities of vegetable oils in the fish diets did not impact the quantity of arachidonic, eicosapentaenoic and docosahexaenoic acid in the fillets and livers. The immunological index and low quantities of linoleic acid in the fillets obtained in group 30SFO/70LO indicate that the $n 3 / n 6$ dietary ratio of 1.35 was the most advantageous for feeding juvenile pikeperch feeds with vegetable oils.

Keywords Pikeperch - Vegetable oils - Fatty acid · Growth · Histological structure · Immunology

\section{Introduction}

Since the early 1990s, studies have been undertaken to determine the possibilities of replacing fish oil (FO) with various vegetable oils (VO) in diets for fish. This has been prompted mainly by economic and 
ecological concerns (Bell et al. 1991; Turchini et al. 2009). It has been established that linseed (LO), sunflower (SFO), soy (SO), peanut (PO), and rapeseed (RO) oils used as the main lipid source in feeds do not lower growth rates in Atlantic salmon (Salmo salar) if appropriate supplies of eicosapentaenoic (C20:5 n-3, EPA) and docosahexaenoic (C22:3 n-3, DHA) acids are provided (Torstensen et al. 2005). Feeding pikeperch (Sander lucioperca) feeds supplemented with vegetable oils (LO, PO) comprising 80\% of the overall quantity of lipids in high-fat feeds (approximately $190 \mathrm{~g}$ fat $/ \mathrm{kg}$ feed) also does not influence fish growth, but it does alter the histological structure of internal organs and the blood biochemical parameters (Kowalska et al. 2010a, b). Increased contents of both linolenic (C18:3 n-3, ALA) and linoleic (C18:2 n-6, LA) in pikeperch diets result in lowered vacuolization in hepatocytes and pyknotic nuclei as well as in increased ceruloplasmin activity in fish blood (Kowalska et al. 2010a, b). In turn, rainbow trout fed diets supplemented with VO with an excess supply of n-3 PUFA result in reduced immune response (Wang et al. 2006). According to Wang et al. (2006) and Lin and Shiau (2007), dietary deficits of essential fatty acids (EFA) suppress immune cell function. While altering the $\mathrm{n} 3 / \mathrm{n} 6$ ratio in feeds (for example, by varied supplementation with corn oil or LO) does not reduce fish growth rates (Karapanagiotidis et al. 2007), it can influence fish condition as indicated by the studies cited earlier. The negative impact on fish condition resulting from feeding them diets supplemented with $\mathrm{VO}$ might be linked to dietary deficits of EPA and DHA, which are lacking in VO and are important for the fish immune system. Moreover, these effects of dietary oils on immunity could be produced by an imbalance in the fatty acid profile of immune cells and/or decrease synthesis of the components of the immune system (Bell et al. 1993; Montero et al. 2003).

Feeding fish feeds supplemented with VO, with dominating LA and ALA, might alter the proximate composition of their bodies (Turchini et al. 2009). While some fish species can bioconvert LA and ALA into highly unsaturated fatty acids (HUFA), physiological accumulation occurs in fish bodies when the diets supply excessive quantities of them (Stubhaug et al. 2005). Oils rich in LA (e.g., SFO) increase the share of n-6 PUFA in salmon fillets (Ruyter et al. 2006), while the addition of oils rich in ALA (e.g.,
LO) can improve the retention in fillets of desirable FA such as EPA and DHA while simultaneously lowering the accumulation of n-6 PUFA (Menoyo et al. 2007). The nutritional quality of meat with high contents of n-6 PUFA is low, which is why attempts are being made to maintain low quantities of these acids in fish fillets. In species such as rainbow trout and pikeperch, the biochemical transformation of ALA to EPA and DHA occurs to a greater degree than that of LA to arachidonic acid (C20:4 n-6, ARA) (Jankowska et al. 2003; Karapanagiotidis et al. 2007). In pikeperch, the effectiveness of HUFA biosynthesis is determined by, among other factors, the $n 3 / n 6$ ratio in feeds (Jankowska et al. 2003). In salmon, the mutual competition of ALA and LA for desaturation enzymes was determined by the quantity of their derivatives in the livers and fillets (Ruyter et al. 2006). The content of FA from the $n-3$ and $n-6$ series in the diet can be modulated using a mixture of $\mathrm{FO}$ and $\mathrm{VO}$ or also using a mixture of $\mathrm{VO}$ with high contents of ALA or LA.

The current study focused on analyzing juvenile pikeperch fed diets supplemented with two VOs that differed mainly in the contents of ALA and LA, e.g., SFO and LO, and determining the impact they had on rearing indexes, the parameters of cellular and humoral-mediated immunity, and the proximate body composition of this species. The feed was supplemented only with SFO, LO, or a mixture of these oils. This permitted formulating diets in which the $\mathrm{n} 3 / \mathrm{n} 6$ ratio ranged from 0.35 to 2.15 .

\section{Materials and methods}

Animals and rearing conditions

The experimental material comprised 6-month-old pikeperch obtained from out-of-season reproduction (Zakęś and Szczepkowski 2004). Fish with an initial body weight of $69.7-71.4 \mathrm{~g}$ were stocked into 12 tanks with a volume of $0.2 \mathrm{~m}^{3}$ in a recirculating aquaculture system. The mean initial stocking density was $11.3 \mathrm{~kg} / \mathrm{m}^{3}$ (33 individuals per tank). The water temperature and oxygen content, total ammonia nitrogen (TAN $=\mathrm{NH}_{3}-\mathrm{N}+\mathrm{NH}_{4}{ }^{+}-\mathrm{N}$ ), and water $\mathrm{pH}$ at the rearing tank outflow were as follows: $21.7 \pm 0.4^{\circ} \mathrm{C}, 5.6 \pm 0.6 \mathrm{mg} \mathrm{O} / 1,0.06 \pm 0.03 \mathrm{mg}$ TAN/l, 7.5-8.2. Water flow in the tanks was $41 / \mathrm{min}$. 
The photoperiod applied was 24L:0D. Light intensity measured at the surface of the rearing tanks was 40-50 lux (Luchiari et al. 2006).

Diets and feeding animals

The feed used to prepare experimental diets was the base feed Aller Safir (Aller-Aqua, Golub-Dobrzyń, Poland) and sunflower (SFO) (ZPT Warsaw, Warsaw, Poland) and linseed oil (LO) (S.P.R.P. Gal, Poznań, Poland). The base feed contained $500 \mathrm{~g}$ crude protein $/ \mathrm{kg}$ feed, $73 \mathrm{~g}$ crude fat $\mathrm{kg} /$ feed, and $80 \mathrm{~g}$ crude ash $/ \mathrm{kg}$ feed on a dry matter basis (granule size $3.0 \mathrm{~mm}$ ). The main source of fat in the base feed was fish meal, while that of protein was fish meal and soy meal. The base feed was supplemented with oils using a vacuum pump (AGA Labor, Lublin, Poland). Four groups of fish were fed the base feed supplemented with SFO (group 100SFO) or LO (group $100 \mathrm{LO}$ ) in quantities of $67 \mathrm{~g} / \mathrm{kg}$ feed or a mixture of the two oils at $47 \mathrm{~g} \mathrm{SFO}$ and $20 \mathrm{~g} \mathrm{LO} \mathrm{kg/feed} \mathrm{(group}$ $70 \mathrm{SFO} / 30 \mathrm{LO}$ ) or $20 \mathrm{~g} \mathrm{SFO}$ and $47 \mathrm{~g} \mathrm{LO} \mathrm{kg/feed}$ (group 30SFO/70LO). Besides SFO and LO oils, the other sources of fatty acids from the $n-3$ and n-6 series in the experimental diets were fish meal and soy meal, respectively. The total fat content of the feed ranged from 129 to $136 \mathrm{~g} / \mathrm{kg}$ feed (Table 1). The contents of protein, fat, and carbohydrates in the experimental feed were within the range recommended for juvenile pikeperch (Nyina-Wamwiza et al. 2005).

The four dietary treatment groups of fish, each in three replicates $(n=3)$, were reared for 8 weeks (56 days) and fed continuously for $19 \mathrm{~h} /$ day with an automatic band feeder (4305 FIAP, Fishtechnic $\mathrm{GmbH}$, Germany). The daily feed ration, set at weekly intervals, was $1.0 \%$ (the first 2 weeks of rearing), $0.9 \%$ (the next 2 weeks of rearing), and $0.8 \%$ (the last 4 weeks of rearing) of the stocking density.

\section{Experimental procedure}

\section{Calculation}

On the first and last days of the experiment, the fish were weighed $(\mathrm{W} \pm 0.01 \mathrm{~g}$ ) and measured (body length, $\mathrm{BL} \pm 0.1 \mathrm{~cm})$. During measurements, the fish were anesthetized with a solution of etomidate at $1.0 \mathrm{ml} / 1$ (Propiscin, IFI Olsztyn, Olsztyn, Poland). The data collected were used to calculate the following parameters:

Specific growth rate (SGR, \%/day)

$$
=100 \times\left[\left(\ln W_{f}-\ln W_{i}\right) / T\right] ;
$$

Daily growth rate $(\mathrm{DGR}, \mathrm{g} /$ day $)=\left(W_{f}-W_{i}\right) / T$;

Fulton's condition factor $(\mathrm{F})=100 \times\left(W / \mathrm{BL}^{3}\right)$;

Coefficient of variation for final body weight $(\mathrm{CV}, \%)$ $=100 \times(\mathrm{SD} / W)$;

Feed conversion ratio $(\mathrm{FCR})=\mathrm{TFI} /(\mathrm{FB}-\mathrm{IB})$;

Protein efficiency ratio $(\mathrm{PER})=(\mathrm{FB}-\mathrm{IB}) / \mathrm{TFP}$;

where $W_{f}$ and $W_{i}$ are the final and initial body weight (g), $T$ - time of rearing (days), BL-fish body length $(\mathrm{cm})$, FB and IB are the final and initial absolute weight ( $\mathrm{g} / \mathrm{fish})$, TFI — total feed intake $(\mathrm{g})$, and TFPtotal feed protein intake $(\mathrm{g})$, At the beginning and the end of the experiment, 15 individuals were taken from each replicate (tank) and their viscera $( \pm 0.01 \mathrm{~g})$ and livers $( \pm 0.001 \mathrm{~g})$ were weighed to determine, among other parameters, the values of the viscerasomatic (VSI) and hepatosomatic (HSI) indexes:

HSI $(\%)=100 \times(\mathrm{LW} / W)$;

VSI $(\%)=100 \times(\mathrm{VW} / W)$;

where LW-liver weight (g), VW-viscera weight (g). The fish used for these tests, as well as those used in the histological, biochemical, and immunological analyses described later, were anesthetized in a solution of etomidate $(4 \mathrm{ml} / \mathrm{l})$ and then decapitated.

\section{Histological analysis}

Histological tests were performed on a sample of eight individuals obtained on the final day of the experiment. The livers were excised, fixed in Bouin's solution, dehydrated in ethanol, cleared in xylene, embedded in paraffin blocks, and cut with a rotation microtome (Leica, Bensheim, Germany) into 5- $\mu \mathrm{m}$ sections and then stained with H\&E. Histological observations were made under a light microscope (Nikon E600, Tokyo, Japan). The analysis was carried out and the structural measurements were taken with the MultiScanBase v. 8.08 (Computer 
Table 1 Proximate (g/kg of dry weight) and selected fatty acid (FA) composition ( $\mathrm{g} \mathrm{FA} / \mathrm{kg}$ of total FA) of the experimental diets

\begin{tabular}{|c|c|c|c|c|}
\hline & \multicolumn{4}{|l|}{ Diets $^{\mathrm{a}}$} \\
\hline & $100 \mathrm{SFO}$ & 70SFO/30LO & 30SFO/70LO & $100 \mathrm{LO}$ \\
\hline \multicolumn{5}{|l|}{ Components } \\
\hline Dry matter & 944.5 & 944.7 & 944.1 & 945.2 \\
\hline Crude protein & 505.0 & 504.2 & 506.3 & 503.7 \\
\hline Crude fat & 133.6 & 130.3 & 136.0 & 128.8 \\
\hline $\mathrm{NFE}^{\mathrm{b}}$ & 276.4 & 275.3 & 270.7 & 285.3 \\
\hline Crude ash & 65.7 & 65.9 & 65.8 & 65.8 \\
\hline Gross energy (MJ/kg feed) & 21.0 & 21.2 & 21.3 & 21.1 \\
\hline \multicolumn{5}{|l|}{ Fatty acid composition } \\
\hline $\mathrm{C} 14: 0$ & 24.2 & 24.8 & 25.0 & 24.5 \\
\hline $\mathrm{C} 16: 0$ & 116.7 & 114.7 & 114.8 & 115.4 \\
\hline $\mathrm{C} 18: 1$ cis 9 & 280.0 & 263.1 & 248.9 & 246.7 \\
\hline C18:2 n-6 & 321.0 & 264.0 & 192.5 & 144.1 \\
\hline C18:3 n-3 & 26.5 & 92.5 & 174.6 & 234.8 \\
\hline C20:4 n-6 & 2.7 & 2.8 & 2.8 & 2.7 \\
\hline C20:5 n-3 & 37.0 & 37.2 & 36.5 & 33.4 \\
\hline $\mathrm{C} 22: 6 \mathrm{n}-3$ & 46.0 & 49.5 & 48.6 & 42.9 \\
\hline Total saturated ${ }^{\mathrm{c}}$ & 176.9 & 176.2 & 175.8 & 179.8 \\
\hline Total monoenes ${ }^{\mathrm{d}}$ & 373.5 & 360.0 & 351.0 & 348.3 \\
\hline Total polyenes ${ }^{\mathrm{e}}$ & 449.5 & 463.7 & 473.2 & 471.9 \\
\hline Total $n-3^{f}$ & 115.7 & 186.0 & 266.5 & 316.3 \\
\hline Total $n-6^{\mathrm{g}}$ & 323.7 & 267.5 & 196.8 & 146.8 \\
\hline Total n- $9^{\text {h }}$ & 299.9 & 284.6 & 268.2 & 270.9 \\
\hline $\mathrm{n} 3 / \mathrm{n} 6$ & 0.36 & 0.70 & 1.35 & 2.15 \\
\hline
\end{tabular}

a $100 \mathrm{SFO}$-feed with sunflower oil (67 g/kg feed), 70SFO/30LO-feed with sunflower and linseed oils (47 and $20 \mathrm{~g} / \mathrm{kg}$ feed), 30SFO/ 70LO-feed with sunflower and linseed oils (20 and $47 \mathrm{~g} / \mathrm{kg}$ feed), 100LO-feed with linseed oil (67 g/kg feed)

b NFE-Nitrogen free extract, calculated as 1,000 - (protein + lipid + ash + fiber) $\mathrm{g} / \mathrm{kg}$

c Total saturated-C14:0, C15:0, C16:0, C18:0, C20:0, C22:0

d Total monoenes-C14:1, C16:1, C17:1, C18:1 cis 9, C18:1 cis 11, C20:1 n-9, C21:1 n-7, C22:1 n-11, C22:1 n-9

e Total polyenes-C16:4, C20:2, C21:5, C18:2 n-6, C20:3 n-6, C40:4 n-6, C22:5 n-6, C18:3 n-3, C20:3 n-3, C20:4 n-3, C20:5 n-3, $\mathrm{C} 22: 5 \mathrm{n}-3, \mathrm{C} 22: 6 \mathrm{n}-3$

${ }^{f}$ Total n-3-C18:3 n-3, C20:3 n-3, C20:4 n-3, C20:5 n-3, C22:5 n-3, C22:6 n-3

g Total n-6-C18:2 n-6, C20:3 n-6, C20:4 n-6, C22:5 n-6

h Total n-9-C18:1 cis 9, C20:1 n-9, C22:1 n-9

Scanning System Ltd., Warsaw, Poland) and NISElements F2.30 v. 2.21 (Nikon, Tokyo, Japan) computer programs.

The size of hepatocytes and their nuclei $( \pm 0.01 \mu \mathrm{m})$ and the nucleocytoplasmic index (ratio of nucleus diameter to hepatocyte diameter) were analyzed in the tissue samples from each individual. Histological measurements were taken from 50 cells and their nuclei in the tissue samples from each individual.

\section{Non-specific cellular and humoral-mediated immunity assays}

At the end of experiment, the blood (from the caudal veins), pronephros, and spleens from eight 
individuals from each of the experimental groups were separated for immunological study $(n=8 ; 2-3$ fish/tank). Blood samples were diluted 1:2 in RPMI 1640 medium (Sigma, USA) without $\mathrm{Ca}^{2+} / \mathrm{Mg}^{2+}$ (Biomed, Poland). The blood was centrifuged to isolate the serum to study non-specific humoralmediated immunity. Leukocytes were isolated from pronephros and the spleens of the fish. The organs were removed aseptically from the fish and pressed through a $60-\mu \mathrm{m}$ nylon mesh in a RPMI-1640 medium (Sigma-Aldrich, St. Louis, Missouri, USA) with L-glutamin and heparin (Biomed, Warsaw, Poland). The cell suspension was placed on density gradients: Gradisol G (Aqua-medica, Łódź, Poland) to isolate phagocytic cells or Gradisol L (Aquamedica, Łódź, Poland) to isolate lymphocytes, and then centrifuged at $400 \mathrm{~g}$ for $40 \mathrm{~min}$ at $4^{\circ} \mathrm{C}$ (Siwicki and Dunier 1990).

The metabolic activity of spleen phagocytes was determined by measuring intracellular respiratory burst activity (RBA) after stimulation with PMA (Phorbol 12-Myristate 13-Acetate, Sigma-Aldrich, St. Louis, Missouri, USA), as described by Chung and Secombes (1988). The technique presented by Secombes (1990) was used to measure the potential killing activity (PKA) of spleen phagocytes. The proliferative response of pronephric lymphocytes stimulated with the mitogens concanavaline A (ConA, Sigma, NY, USA) or lipopolysaccharide (LPS, Sigma, NY, USA) was determined using the MTT [3-(4,5dimethylthiazol-2-yl)-2,5-diphenyltetrazolium bromide, (Sigma, NY, USA)] colorimetric assay according to the method presented by Mosmann (1983).

The lysozyme activity in the serum was measured in a turbidimetric assay described by Siwicki and Anderson (1993). The standard used was hen egg white lysozyme (Sigma-Aldrich, St. Louis, Missouri, USA) and a Micrococcus lysodeicticus (SigmaAldrich, St. Louis, Missouri, USA) suspension in phosphate buffer. The ceruloplasmin activity in the serum was determined spectrophotometrically according to the method presented for Rice et al. (1986). The total protein level in the serum was measured with the colorimetric Lowry micro method described in Siwicki et al. (2003), and total immunoglobulin (Ig) levels in serum were measured using the Lowry micro method with modifications described in Siwicki and Anderson (1993). This technique consists of first precipitating the total Ig from the serum with polyethylene glycol $(10,000 \mathrm{kDa})$ and, after centrifuging, removing the supernatant and determining the amount of remaining proteins with a microreader at a wavelength of $540 \mathrm{~nm}$ (Mrx Dynex, Technologies, Billingshurst, UK).

\section{Biochemical analysis of proximate and fatty acid composition}

The proximate composition of the fish was analyzed on the first and last days of the experiment (20 fish from each tank). The proximate composition was determined in samples of whole fish -5 individuals, fillets (skinless) -6 , viscera-15, livers -15 . The fish and body parts obtained from the same tank were combined and analyzed together $(n=3$, for each dietary treatment). The contents of water, total protein, raw fats, and raw ash (wet weight) were determined in prepared samples of whole fish, viscera, and fillets. On the final day of the experiment, the samples listed earlier and the livers were analyzed for the contents of particular fatty acids (g/ $\mathrm{kg}$ of total fatty acid (tFA)). The proximate composition and fatty acid contents were also determined in the experimental feeds. The content of protein was determined with the Kjeldahl method. Fat content was determined with the Soxhlet method (AOAC 1975). The analysis of fatty acids (qualitative and quantitative) was conducted according to the method described in Folch et al. (1957). The fatty acids were methylated using a mixture of chloroform, anhydrous methanol, and sulfuric acid (100:100:1) (Peisker 1964). Chromatographic separation was performed with an Agilent Technologies $6890 \mathrm{~N}$ gas chromatograph with a flame ionization detector (FID). The detector signal was registered with a Philips brand device on a scale of $1 \mathrm{mV}$ at a tape speed of $10 \mathrm{~mm} /$ min. The fatty acids were identified with standards from Supelco (Bellefonte, PA, USA).

\section{Statistical analysis}

The results of all the measurements and calculations were subjected to statistical analysis with the GraphPad Prism program (Soft. Inc., Avenida de la Playa, La Jolla, CA, USA). The means were compared with single factor analysis of variance (ANOVA). When statistically significant differences were confirmed 
among dietary treatments $(P \leq 0.05)$, further statistical analysis was performed with Tukey's test. All values expressed as percentages were transformed with $\arcsin$ before statistical processing.

\section{Results}

Growth and feed utilization

Feeding pikeperch the tested feeds for 56 days did not have a significant impact on fish growth. The mean final body weight of pikeperch ranged from 108 to $113 \mathrm{~g}$, and the values of the SGR and DGR were also similar (Table 2). No significant differences were noted between the FCR, PER, or VSI coefficients (Table 3).

Liver histology, immunology, and blood chemistry

The experimental diets fed to the pikeperch did not affect the values of the HSI or the size of the hepatocytes or their nuclei (Table 4). The value of the nucleo-cytoplasmic ratio ranged from 0.30 to 0.31 .

Supplementing feed with one type of vegetable oil (groups 100SFO and 100LO) significantly lowered the values of the immunological indexes analyzed (Table 5). Lower metabolic activity and intracellular phagocyte killing activity were noted in the pikeperch fed these feeds in comparison with the 70SFO/30LO and 30SFO/70LO groups (Table 5). The proliferative lymphocyte activity of the fish from groups $100 \mathrm{SFO}$ and 100LO was lower by $15-20 \%$ in comparison with that of the 70SFO/30LO and 30SFO/70LO groups (Table 5). Moreover, the lysozyme activity in group $100 \mathrm{LO}$ was significantly the lowest $(21.36 \mathrm{mg} / \mathrm{l}$; Table 6). In turn, the highest ceruloplasmin activity was confirmed in the fish from group 100SFO (77.14 IU; Table 6).

Chemical composition of pikeperch bodies

No significant differences were noted in the quantity of water, protein, fat, or ash in the whole bodies, fillets, or viscera of the fish from the tested groups (Table 7). The contents of saturated fatty acids (SFA), monounsaturated fatty acids (MUFA), and PUFA were similar in the whole fish bodies, fillets, and livers (Tables 8, 9, 11). In turn, significantly higher quantities of SFA and MUFA and lower quantities of PUFA were noted in the viscera of the fish from the 100SFO group in comparison with the other dietary treatments (Table 10). The whole bodies of fish from the 100SFO group were characterized by the highest content of total $\mathrm{n}-6(195.2 \mathrm{~g} / \mathrm{kg}$ tFA $)$, while the 100LO group had the highest content of total n-3 (244.6 g/kg tFA) (Table 8). The content of total $\mathrm{n}-3$ in the fish meat ranged from 278.5 to $340.8 \mathrm{~g} / \mathrm{kg}$ tFA (groups 100SFO and 100LO; Table 9); however, it was higher than total n-6 and n-9 in all the groups. While the content of total $n-9$ was higher than that of n-3 and of $n-6$ in the viscera of fish from the 100SFO, 70SFO/30LO, and 30SFO/70LO groups, the contents of total n-9 and of n-3 were

Table 2 Rearing parameters of pikeperch fed experimental diets for 56 days (mean $\pm \mathrm{SD} ; n=3$ )

\begin{tabular}{|c|c|c|c|c|}
\hline & \multicolumn{4}{|c|}{ Dietary treatments ${ }^{\mathrm{a}}$} \\
\hline & 100SFO & 70SFO/30LO & 30SFO/70LO & 100LO \\
\hline Initial body weight $(\mathrm{g})$ & $71.39 \pm 0.56$ & $70.55 \pm 0.94$ & $69.71 \pm 2.66$ & $70.96 \pm 0.81$ \\
\hline Final body weight $(\mathrm{g})$ & $112.58 \pm 0.01$ & $108.13 \pm 6.13$ & $111.33 \pm 0.57$ & $112.28 \pm 3.68$ \\
\hline Daily growth rate DGR (g/day) & $0.66 \pm 0.08$ & $0.61 \pm 0.07$ & $0.74 \pm 0.05$ & $0.74 \pm 0.06$ \\
\hline Specific growth rate SGR (\%/day) & $0.82 \pm 0.01$ & $0.76 \pm 0.08$ & $0.84 \pm 0.07$ & $0.82 \pm 0.05$ \\
\hline Final coefficient of body weight variation $\mathrm{CV}_{\mathrm{f}}(\%)$ & $35.42 \pm 0.23$ & $37.64 \pm 3.49$ & $36.90 \pm 3.85$ & $34.91 \pm 3.13$ \\
\hline Final Fulton's condition factor $F_{f}$ & $1.20 \pm 0.01$ & $1.21 \pm 0.01$ & $1.21 \pm 0.04$ & $1.22 \pm 0.02$ \\
\hline
\end{tabular}

Absence of superscript letters indicates no significant differences among treatments $(P>0.05)$

a 100 SFO-group fed feed with sunflower oil (67 g/kg feed), 70SFO/30LO-group fed feed with sunflower and linseed oils (47 and $20 \mathrm{~g} / \mathrm{kg}$ feed), 30SFO/70LO-group fed feed with sunflower and linseed oils (20 and $47 \mathrm{~g} / \mathrm{kg}$ feed), 100LO-group fed feed with linseed oil $(67 \mathrm{~g} / \mathrm{kg}$ feed $)$ 
Table 3 Feed utilization and viscerosomatic index in pikeperch fed experimental diets for 56 days (mean \pm SD; $n=3$ and $n=15$ for VSI)

\begin{tabular}{|c|c|c|c|c|}
\hline & \multicolumn{4}{|c|}{ Dietary treatments ${ }^{\mathrm{a}}$} \\
\hline & $100 \mathrm{SFO}$ & 70SFO/30LO & 30SFO/70LO & $100 \mathrm{LO}$ \\
\hline Feed conversion ratio FCR & $0.94 \pm 0.01$ & $1.02 \pm 0.09$ & $0.91 \pm 0.04$ & $0.93 \pm 0.03$ \\
\hline Protein efficiency ratio PER & $2.11 \pm 0.01$ & $1.95 \pm 0.18$ & $2.18 \pm 0.10$ & $2.12 \pm 0.08$ \\
\hline Viscerosomatic index VSI (\%) & $8.36 \pm 0.29$ & $8.03 \pm 0.06$ & $8.04 \pm 1.15$ & $8.22 \pm 1.20$ \\
\hline
\end{tabular}

Absence of superscript letters indicates no significant differences among treatments $(P>0.05)$

a 100SFO-group fed feed with sunflower oil (67 g/kg feed), 70SFO/30LO-group fed feed with sunflower and linseed oils (47 and $20 \mathrm{~g} / \mathrm{kg}$ feed), 30SFO/70LO-group fed feed with sunflower and linseed oils (20 and $47 \mathrm{~g} / \mathrm{kg}$ feed), 100LO-group fed feed with linseed oil $(67 \mathrm{~g} / \mathrm{kg}$ feed $)$

Table 4 Comparison of hepatosomatic index and hepatocyte morphometric characteristics of pikeperch fed experimental diets (see Table 1) (mean $\pm \mathrm{SD} ; n=8$ and $n=15$ for HSI)

\begin{tabular}{|c|c|c|c|c|}
\hline & \multicolumn{4}{|c|}{ Dietary treatments ${ }^{\mathrm{a}}$} \\
\hline & 100SFO & 70SFO/30LO & 30SFO/70LO & 100LO \\
\hline Hepatosomatic index HSI (\%) & $1.43 \pm 0.05$ & $1.48 \pm 0.33$ & $1.44 \pm 0.43$ & $1.44 \pm 0.07$ \\
\hline Size of hepatocyte $(\mu \mathrm{m})$ & $15.2 \pm 1.3$ & $15.0 \pm 0.7$ & $15.3 \pm 1.1$ & $15.5 \pm 0.5$ \\
\hline Size of nuclei $(\mu \mathrm{m})$ & $4.4 \pm 0.2$ & $4.5 \pm 0.1$ & $4.6 \pm 0.1$ & $4.6 \pm 0.2$ \\
\hline Nucleo-cytoplasmic ratio N/C & $0.30 \pm 0.04$ & $0.31 \pm 0.02$ & $0.31 \pm 0.02$ & $0.30 \pm 0.2$ \\
\hline
\end{tabular}

Absence of superscript letters indicates no significant differences among treatments $(P>0.05)$

a 100SFO-group fed feed with sunflower oil $(67 \mathrm{~g} / \mathrm{kg}$ feed), 70SFO/30LO-group fed feed with sunflower and linseed oils (47 and $20 \mathrm{~g} / \mathrm{kg}$ feed), 30SFO/70LO-group fed feed with sunflower and linseed oils (20 and $47 \mathrm{~g} / \mathrm{kg}$ feed), 100LO-group fed feed with linseed oil $(67 \mathrm{~g} / \mathrm{kg}$ feed $)$

Table 5 The cell-mediated immunity in pikeperch fed experimental diets for 56 days (mean $\pm \mathrm{SD} ; n=8$ )

\begin{tabular}{|c|c|c|c|c|}
\hline & \multicolumn{4}{|c|}{ Dietary treatments ${ }^{\mathrm{a}}$} \\
\hline & 100SFO & $\begin{array}{l}70 \mathrm{SFO} / \\
30 \mathrm{LO}\end{array}$ & 30SFO/70LO & $100 \mathrm{LO}$ \\
\hline Metabolic ability of spleen phagocytes (RBA; OD $620 \mathrm{~nm}$ ) & $0.37^{\mathrm{a}} \pm 0.03$ & $0.46^{\mathrm{b}} \pm 0.05$ & $0.45^{\mathrm{b}} \pm 0.04$ & $0.35^{\mathrm{a}} \pm 0.04$ \\
\hline Potential killing activity of spleen phagocytes (PKA; OD $620 \mathrm{~nm}$ ) & $0.41^{\mathrm{a}} \pm 0.04$ & $0.49^{\mathrm{b}} \pm 0.04$ & $0.47^{\mathrm{b}} \pm 0.0 .5$ & $0.38^{\mathrm{a}} \pm 0.03$ \\
\hline $\begin{array}{l}\text { Lymphocyte proliferation stimulated by ConA (LP-ConA; OD } \\
620 \mathrm{~nm} \text { ) }\end{array}$ & $0.51^{\mathrm{a}} \pm 0.03$ & $0.58^{b} \pm 0.03$ & $0.56^{\mathrm{b}} \pm 0.04$ & $0.48^{\mathrm{a}} \pm 0.04$ \\
\hline Lymphocyte proliferation stimulated by LPS (LP-LPS OD $620 \mathrm{~nm}$ ) & $0.33^{\mathrm{a}} \pm 0.04$ & $0.39^{\mathrm{b}} \pm 0.04$ & $0.38^{\mathrm{b}} \pm 0.04$ & $0.31^{\mathrm{a}} \pm 0.03$ \\
\hline
\end{tabular}

Absence of superscript letters indicates no significant differences among treatments $(P>0.05)$

a $100 \mathrm{SFO}$-group fed feed with sunflower oil (67 g/kg feed), 70SFO/30LO-group fed feed with sunflower and linseed oils (47 and $20 \mathrm{~g} / \mathrm{kg}$ feed), 30SFO/70LO-group fed feed with sunflower and linseed oils (20 and $47 \mathrm{~g} / \mathrm{kg}$ feed), 100LO-group fed feed with linseed oil $(67 \mathrm{~g} / \mathrm{kg}$ feed $)$

similar in group 100LO. The dominant FA in all of the pikeperch body parts analyzed was oleic acid, while the highest contents of it were confirmed in the viscera of the fish from group 100SFO $(268.0 \mathrm{~g} /$ $\mathrm{kg}$ tFA; Tables 8, 9, 10, 11). Significant differences in the contents of ALA and LA were noted among groups in all of the body parts analyzed (Tables 8 ,
9, 10, 11). The contents of LA compared with those of ALA were more than threefold higher in all of the body parts in group 100SFO. The feed fed to the fish from this group contained $295 \mathrm{~g} / \mathrm{kg}$ tFA more LA than ALA, and the differences in the content of these FA in the fish bodies reflected their concentrations in the feed. In group 100LO, the feed 
Table 6 Humoral-mediated immunity in pikeperch fed experimental diets for 56 days (mean \pm SD; $n=8$ )

\begin{tabular}{lccrrr}
\hline & \multicolumn{1}{l}{ Dietary treatments ${ }^{\mathrm{a}}$} & & & \\
\cline { 2 - 5 } & \multicolumn{1}{l}{ 100SFO } & 70SFO/30LO & 30SFO/70LO & $100 \mathrm{LO}$ \\
\hline Lysozyme activity in serum (mg/l) & $29.79^{\mathrm{ab}} \pm 9.86$ & $30.35^{\mathrm{ab}} \pm 4.93$ & $32.01^{\mathrm{b}} \pm 6.64$ & $21.36^{\mathrm{a}} \pm 5.29$ \\
Ceruloplasmin (Cp) activity in serum (IU) & $77.14^{\mathrm{c}} \pm 10.38$ & $56.64^{\mathrm{ab}} \pm 3.02$ & $58.84^{\mathrm{a}} \pm 6.28$ & $67.54^{\mathrm{bc}} \pm 7.87$ \\
Total protein level in serum (g/l) & $50.06 \pm 5.64$ & $53.78 \pm 5.77$ & $53.59 \pm 3.24$ & $49.62 \pm 3.95$ \\
Total gammaglobulin level in serum (g/l) & $6.78^{\mathrm{ab}} \pm 1.96$ & $7.56^{\mathrm{b}} \pm 2.28$ & $5.96^{\mathrm{ab}} \pm 1.46$ & $4.34^{\mathrm{a}} \pm 1.32$ \\
\hline
\end{tabular}

Absence of superscript letters indicates no significant differences among treatments $(P>0.05)$

a 100 SFO-group fed feed with sunflower oil (67 g/kg feed), 70SFO/30LO-group fed feed with sunflower and linseed oils (47 and $20 \mathrm{~g} / \mathrm{kg}$ feed), 30SFO/70LO-group fed feed with sunflower and linseed oils ( 20 and $47 \mathrm{~g} / \mathrm{kg}$ feed), 100LO-group fed feed with linseed oil $(67 \mathrm{~g} / \mathrm{kg}$ feed $)$

Table 7 Proximate composition (g/kg of wet weight) of whole body, fillets and viscera of juvenile pikeperch fed experimental diets with varying lipid sources (see Table 1$)$ (mean $\pm \mathrm{SD} ; n=3$ )

\begin{tabular}{|c|c|c|c|c|}
\hline & \multicolumn{4}{|l|}{$\operatorname{Diets}^{\mathrm{a}}$} \\
\hline & 100SFO & 70SFO/30LO & 30SFO/70LO & $100 \mathrm{LO}$ \\
\hline \multicolumn{5}{|l|}{ Whole body } \\
\hline Water & $716.6 \pm 5.2$ & $716.7 \pm 4.3$ & $725.4 \pm 8.6$ & $716.8 \pm 9.2$ \\
\hline Crude protein & $178.4 \pm 5.7$ & $179.0 \pm 4.4$ & $175.7 \pm 5.1$ & $178.7 \pm 2.3$ \\
\hline Crude fat & $68.7 \pm 0.3$ & $67.9 \pm 0.2$ & $62.6 \pm 8.2$ & $69.4 \pm 8.9$ \\
\hline Crude ash & $33.4 \pm 1.3$ & $34.3 \pm 0.9$ & $33.2 \pm 0.5$ & $34.0 \pm 0.9$ \\
\hline Gross energy $(\mathrm{MJ} / \mathrm{kg})$ & $6.9 \pm 0.1$ & $6.9 \pm 0.1$ & $6.7 \pm 0.3$ & $6.9 \pm 0.4$ \\
\hline \multicolumn{5}{|l|}{ Fillet } \\
\hline Water & $780.7 \pm 3.0$ & $783.7 \pm 0.6$ & $782.1 \pm 0.5$ & $782.4 \pm 2.2$ \\
\hline Crude protein & $195.4 \pm 0.7$ & $192.4 \pm 1.0$ & $195.7 \pm 3.0$ & $194.2 \pm 1.6$ \\
\hline Crude fat & $6.3 \pm 1.4$ & $7.5 \pm 0.2$ & $6.7 \pm 2.1$ & $6.6 \pm 1.8$ \\
\hline Crude ash & $13.6 \pm 0.6$ & $13.8 \pm 0.2$ & $13.8 \pm 0.2$ & $13.4 \pm 0.6$ \\
\hline Gross energy $(\mathrm{MJ} / \mathrm{kg})$ & $4.9 \pm 0.1$ & $4.9 \pm 0.1$ & $4.9 \pm 0.1$ & $4.9 \pm 0.1$ \\
\hline \multicolumn{5}{|l|}{ Viscera } \\
\hline Water & $196.0 \pm 0.8$ & $201.2 \pm 6.0$ & $199.2 \pm 16.1$ & $209.0 \pm 13.5$ \\
\hline Crude protein & $41.1 \pm 15.5$ & $60.2 \pm 21.2$ & $62.8 \pm 17.7$ & $59.1 \pm 3.6$ \\
\hline Crude fat & $750.8 \pm 19.2$ & $724.8 \pm 32.7$ & $734.0 \pm 8.7$ & $722.7 \pm 8.9$ \\
\hline Crude ash & $2.6 \pm 0.2$ & $2.1 \pm 0.2$ & $2.1 \pm 0.4$ & $2.3 \pm 0.4$ \\
\hline Gross energy $(\mathrm{MJ} / \mathrm{kg})$ & $30.1 \pm 0.6$ & $29.7 \pm 0.8$ & $30.1 \pm 0.4$ & $29.6 \pm 0.4$ \\
\hline
\end{tabular}

Absence of superscript letters indicates no significant differences among treatments $(P>0.05)$

a $100 \mathrm{SFO}-$ feed with sunflower oil (67 g/kg feed), 70SFO/30LO-feed with sunflower and linseed oils (47 and $20 \mathrm{~g} / \mathrm{kg}$ feed), 30SFO/ $70 \mathrm{LO}-$ feed with sunflower and linseed oils (20 and $47 \mathrm{~g} / \mathrm{kg}$ feed), 100LO-feed with linseed oil (67 $\mathrm{g} / \mathrm{kg}$ feed)

contained $91 \mathrm{~g} / \mathrm{kg}$ tFA more ALA than LA, and the quantities of these FA in the analyzed body parts were similar. The quantities of ARA, EPA, and DHA in the fillets and livers of the four dietary treatments were similar (Tables 9,11 ). The $n-3 / n 6$ ratio in pikeperch fillets was the most advantageous in groups 100LO and 30SFO/70LO (Table 9).

\section{Discussion}

Growth and nutrient utilization

Juvenile pikeperch growth in the dietary treatment groups tested was similar and comparable with that obtained for pikeperch reared in recirculating systems 
Table 8 Fatty acid (FA) composition (g FA/kg total FA) of whole bodies of pikeperch fed diets with different lipid sources (see Table 1) (mean $\pm \mathrm{SD} ; n=3$ )

\begin{tabular}{|c|c|c|c|c|}
\hline & \multicolumn{4}{|c|}{ Dietary treatments ${ }^{\mathrm{a}}$} \\
\hline & 100SFO & 70SFO/30LO & 30SFO/70LO & $100 \mathrm{LO}$ \\
\hline $\mathrm{C} 14: 0$ & $39.5 \pm 3.3$ & $45.2 \pm 1.4$ & $42.9 \pm 3.0$ & $45.3 \pm 1.8$ \\
\hline C16:0 & $157.3 \pm 1.6$ & $160.5 \pm 6.0$ & $150.1 \pm 4.0$ & $164.5 \pm 9.3$ \\
\hline $\mathrm{C} 18: 1$ cis 9 & $251.5 \pm 0.5$ & $246.3 \pm 9.1$ & $242.5 \pm 4.9$ & $248.0 \pm 4.8$ \\
\hline C18:2 n-6 & $186.9^{\mathrm{d}} \pm 0.8$ & $159.3^{\mathrm{c}} \pm 5.1$ & $143.9^{\mathrm{b}} \pm 1.0$ & $124.1^{\mathrm{a}} \pm 4.4$ \\
\hline C18:3 n-3 & $58.5^{\mathrm{a}} \pm 2.0$ & $75.2^{\mathrm{b}} \pm 3.6$ & $103.0^{\mathrm{c}} \pm 2.8$ & $118.8^{\mathrm{d}} \pm 4.7$ \\
\hline C20:4 n-6 & $5.0 \pm 0.1$ & $5.0 \pm 0.2$ & $5.3 \pm 0.2$ & $4.7 \pm 0.4$ \\
\hline C20:5 n-3 & $52.2 \pm 1.1$ & $50.0 \pm 2.7$ & $53.7 \pm 3.3$ & $51.9 \pm 4.0$ \\
\hline$C 22: 6 n-3$ & $69.6^{\mathrm{a}} \pm 0.9$ & $67.9^{\mathrm{a}} \pm 3.0$ & $73.7^{\mathrm{b}} \pm 4.8$ & $60.3^{\mathrm{a}} \pm 5.5$ \\
\hline Total saturated & $219.6 \pm 2.5$ & $229.9 \pm 7.0$ & $217.6 \pm 5.9$ & $234.7 \pm 11.7$ \\
\hline Total monoenes & $376.7 \pm 0.7$ & $383.8 \pm 7.4$ & $372.6 \pm 7.7$ & $376.7 \pm 11.4$ \\
\hline Total polyenes & $400.7 \pm 1.8$ & $386.3 \pm 5.9$ & $409.8 \pm 13.5$ & $386.6 \pm 19.6$ \\
\hline Total n-3 & $193.6^{\mathrm{a}} \pm 2.3$ & $206.5^{\mathrm{a}} \pm 9.8$ & $244.6^{\mathrm{b}} \pm 11.6$ & $244.6^{\mathrm{b}} \pm 14.6$ \\
\hline Total n-6 & $195.2^{\mathrm{d}} \pm 0.9$ & $167.4^{\mathrm{c}} \pm 5.3$ & $152.3^{\mathrm{b}} \pm 1.4$ & $131.6^{\mathrm{a}} \pm 5.0$ \\
\hline Total n-9 & $270.5 \pm 0.3$ & $267.1 \pm 1.1$ & $261.7 \pm 5.5$ & $268.3 \pm 7.0$ \\
\hline $\mathrm{n} 3 / \mathrm{n} 6$ & $0.99 \pm 0.02$ & $1.24 \pm 0.09$ & $1.61 \pm 0.07$ & $1.86 \pm 0.07$ \\
\hline
\end{tabular}

Different superscript letters on the same line denotes significant differences $(P<0.05)$

a 100 SFO-group fed feed with sunflower oil (67 g/kg feed), 70SFO/30LO-group fed feed with sunflower and linseed oils (47 and $20 \mathrm{~g} / \mathrm{kg}$ feed), 30SFO/70LO-group fed feed with sunflower and linseed oils (20 and $47 \mathrm{~g} / \mathrm{kg}$ feed), 100LO-group fed feed with linseed oil $(67 \mathrm{~g} / \mathrm{kg}$ feed); for explanation of fatty acid groups see Table 1

and fed commercial trout feed (Zakęś et al. 2010). As was noted with salmonid fish, the quality of fat in the pikeperch diets (LO and SFO applied exclusively or in a mixture) did not impact the value of the feed conversion ratio (Karalazos et al. 2007; this study). Experimental diets containing VO fed to salmonids also did not affect growth rates or FCR because, among other factors, the appropriate quantities of EPA and DHA (minimum $16 \mathrm{~g} / \mathrm{kg}$ tFA) were supplied by either fish meal or certain quantities of fish oil in the feed (Turchini et al. 2009). In the case of the pikeperch, the application of the commercial trout feed base, which contained fish meal and probably supplied levels of EPA and DHA required by this species, could have resulted in the acceptable growth and advantageous FCR. Additionally, the current study and studies cited fed subjects highenergy feeds that contained the recommended quantities of protein for the species analyzed. If the quantity of protein is appropriate for pikeperch (400 and $500 \mathrm{~g}$ protein $/ \mathrm{kg}$ feed), then differences neither in the quality of oils (FO, PO, LO, SO, RO, SFO) nor in the quantity (range of $100-220 \mathrm{~g}$ fat $/ \mathrm{kg}$ feed) impact the effects of rearing (Nyina-Wamwiza et al. 2005; Kowalska et al. 2010a, b; Zakęś et al. 2010, this study).

Health of fish. Liver histology and cellular and humoral-mediated immunity

The liver is the primary site for lipid metabolism, which is why the quality of the fat in feeds can impact the values of the HSI (Schulz et al. 2005). In the current experiment, the different contents of ALA and LA in the feeds tested did not influence liver size, and the size of the hepatocytes and their nuclei was similar in all four dietary treatment groups. Pathological changes in the livers of pikeperch were noted when quantities of myristic acid (141 g FA/kg tFA), palmitic acid (90 g FA/kg tFA), EPA, and DHA (51 g FA/kg tFA) were low and those of ALA (355 g FA/kg tFA) very high (Kowalska et al. 2010b). Disturbances in dietary fat digestibility in salmon were noted at quantities of palmitic acid below $100 \mathrm{~g}$ FA/kg tFA (Menoyo et al. 2007), and anomalies in hepatocyte structure were noted in European seabass, 
Table 9 Fatty acid (FA) composition (g FA/kg total FA) of fillets of pikeperch fed diets with different lipid sources (see Table 1) (mean $\pm \mathrm{SD} ; n=3$ )

\begin{tabular}{|c|c|c|c|c|}
\hline & \multicolumn{4}{|c|}{ Dietary treatments ${ }^{\mathrm{a}}$} \\
\hline & 100SFO & 70SFO/30LO & 30SFO/70LO & $100 \mathrm{LO}$ \\
\hline C14:0 & $25.4 \pm 0.1$ & $25.9 \pm 1.7$ & $26.7 \pm 4.1$ & $28.0 \pm 1.5$ \\
\hline C16:0 & $184.0 \pm 1.7$ & $188.5 \pm 6.9$ & $202.5 \pm 17.7$ & $193.9 \pm 2.4$ \\
\hline $\mathrm{C} 18: 1$ cis 9 & $213.0 \pm 34.5$ & $183.0 \pm 10.4$ & $186.1 \pm 4.4$ & $184.6 \pm 11.5$ \\
\hline C18:2 n-6 & $133.2^{\mathrm{b}} \pm 5.2$ & $130.1^{\mathrm{b}} \pm 7.6$ & $105.2^{\mathrm{a}} \pm 7.4$ & $101.1^{\mathrm{a}} \pm 6.0$ \\
\hline C18:3 n-3 & $39.3^{\mathrm{a}} \pm 4.5$ & $52.6^{\mathrm{b}} \pm 3.2$ & $67.6^{c} \pm 8.9$ & $92.8^{\mathrm{d}} \pm 7.2$ \\
\hline C20:4 n-6 & $8.3 \pm 1.0$ & $8.9 \pm 1.4$ & $8.2 \pm 0.3$ & $8.4 \pm 0.6$ \\
\hline C20:5 n-3 & $56.2 \pm 3.9$ & $59.6 \pm 5.6$ & $53.7 \pm 3.3$ & $60.3 \pm 0.4$ \\
\hline$C 22: 6 n-3$ & $168.4 \pm 20.0$ & $176.1 \pm 17.6$ & $166.8 \pm 16.6$ & $171.1 \pm 11.9$ \\
\hline Total saturated & $254.6 \pm 2.9$ & $261.3 \pm 7.2$ & $280.8 \pm 25.1$ & $265.8 \pm 4.4$ \\
\hline Total monoenes & $310.8 \pm 36.1$ & $282.9 \pm 19.5$ & $290.2 \pm 9.0$ & $376.7 \pm 11.4$ \\
\hline Total polyenes & $434.7 \pm 33.2$ & $455.8 \pm 15.6$ & $429.1 \pm 34.1$ & $464.9 \pm 19.1$ \\
\hline Total n-3 & $278.5^{\mathrm{a}} \pm 28.1$ & $303.5^{\mathrm{ab}} \pm 20.6$ & $302.2^{\mathrm{ab}} \pm 25.6$ & $340.8^{b} \pm 13.3$ \\
\hline Total n-6 & $146.0^{\mathrm{b}} \pm 6.5$ & $143.3^{\mathrm{b}} \pm 6.1$ & $117.2^{\mathrm{a}} \pm 8.2$ & $113.6^{\mathrm{a}} \pm 6.0$ \\
\hline Total n-9 & $234.1 \pm 36.7$ & $199.1 \pm 10.8$ & $204.1 \pm 3.3$ & $200.5 \pm 10.9$ \\
\hline $\mathrm{n} 3 / \mathrm{n} 6$ & $1.90^{\mathrm{a}} \pm 0.11$ & $2.12^{\mathrm{a}} \pm 0.23$ & $2.58^{\mathrm{b}} \pm 0.14$ & $3.00^{c} \pm 0.09$ \\
\hline
\end{tabular}

Different superscript letters on the same line denotes significant differences $(P<0.05)$

a 100 SFO-group fed feed with sunflower oil (67 g/kg feed), 70SFO/30LO-group fed feed with sunflower and linseed oils (47 and $20 \mathrm{~g} / \mathrm{kg}$ feed), 30SFO/70LO-group fed feed with sunflower and linseed oils (20 and $47 \mathrm{~g} / \mathrm{kg}$ feed), 100LO-group fed feed with linseed oil $(67 \mathrm{~g} / \mathrm{kg}$ feed); for explanation of fatty acid groups see Table 1

Dicentrarchus labrax, when amount of EPA and DHA was lower than $100 \mathrm{~g} \mathrm{FA} / \mathrm{kg}$ tFA (Parpoura and Alexis 2001). In the current experiment, none of the FA mentioned earlier were deficient in the feeds tested, and the quantities of ALA did not exceed $235 \mathrm{~g} \mathrm{FA} / \mathrm{kg}$ tFA. This is probably why no pathological changes were noted in the pikeperch livers.

Our earlier study indicates that even though lipid sources may cause some metabolic disorders in fish, their manifestation is not always seen in the histology of organs (Kowalska et al. 2010b). Thus, the analysis of blood parameters, including $\mathrm{Cp}$, could be used as a marker in diagnosing changes in fish health resulting from improperly composed diets. In this study, while the high levels of ALA or LA in the experimental feeds did not cause any pathological changes in the livers, they did increase significantly $\mathrm{Cp}$ activity in the fish blood. Increased $\mathrm{Cp}$ activity is linked to anomalies in the regulation of its secretion, changes in the liver structure, and low levels of n-3 PUFA in fish diets (Cousin 1985; Kowalska et al. 2010a, b). This is probably why the significantly highest $\mathrm{Cp}$ activity was noted in the group of fish fed feed
100SFO, which had the lowest n-3 PUFA content (total $\mathrm{n}-3=116 \mathrm{~g} \mathrm{FA} / \mathrm{kg} \mathrm{tFA}$ ) especially in regard to ALA content (precursor of DHA and EPA). The Cp activity was nearly threefold lower in pikeperch ( $W=60 \mathrm{~g}$ and $W=400 \mathrm{~g}$ ) reared in recirculation systems and fed commercial trout feed (total $\mathrm{n}-3=310 \mathrm{~g}$ FA/kg tFA) (Siwicki et al. 2006, Kowalska et al. 2010b). The results obtained indicate that the low level of n-3 PUFA in the pikeperch diet causes increased values of $\mathrm{Cp}$ in the blood, which might be explained by impaired hepatocyte function. Anomalies in hepatocyte structure were observed in fish fed feeds poor in EPA and DHA, but this effect was leveled with increased contents of these FA in the feed (Parpoura and Alexis 2001). Disturbances in the regulations of $\mathrm{Cp}$ expression can be connected with abnormalities in hepatocyte structures (Cousin 1985, Kowalska et al. 2010a).

Montero et al. (2003) and Wang et al. (2006) reported that the lysozyme activity in gilthead seabream, Sparus aurata, was not dependent on the FA composition of the diet. However, in the current study, the value of this parameter in the blood of pikeperch 
Table 10 Fatty acid (FA) composition (g FA/kg total FA) of viscera from pikeperch fed diets with different lipid sources (see Table 1) (mean $\pm \mathrm{SD} ; n=3)$

\begin{tabular}{|c|c|c|c|c|}
\hline & \multicolumn{4}{|c|}{ Dietary treatments $^{\mathrm{a}}$} \\
\hline & $100 \mathrm{SFO}$ & 70SFO/30LO & 30SFO/70LO & $100 \mathrm{LO}$ \\
\hline $\mathrm{C} 14: 0$ & $51.2 \pm 1.7$ & $48.0 \pm 1.0$ & $48.5 \pm 1.1$ & $48.8 \pm 1.1$ \\
\hline C16:0 & $151.3 \pm 1.2$ & $141.0 \pm 4.1$ & $142.8 \pm 4.1$ & $140.8 \pm 5.7$ \\
\hline $\mathrm{C} 18: 1$ cis 9 & $268.0^{\mathrm{b}} \pm 5.7$ & $251.3^{\mathrm{a}} \pm 1.4$ & $247.8^{\mathrm{a}} \pm 2.2$ & $243.7^{\mathrm{a}} \pm 3.9$ \\
\hline C18:2 n-6 & $187.2^{\mathrm{d}} \pm 0.8$ & $172.3^{\mathrm{c}} \pm 2.4$ & $151.5^{\mathrm{b}} \pm 2.2$ & $134.6^{\mathrm{a}} \pm 0.6$ \\
\hline $\mathrm{C} 18: 3 \mathrm{n}-3$ & $66.2^{\mathrm{a}} \pm 1.4$ & $91.3^{\mathrm{b}} \pm 0.8$ & $119.0^{c} \pm 2.4$ & $138.2^{\mathrm{d}} \pm 2.6$ \\
\hline C20:4 n-6 & $3.9 \pm 0.3$ & $4.6 \pm 0.3$ & $4.2 \pm 0.2$ & $4.4 \pm 0.3$ \\
\hline $\mathrm{C} 20: 5 \mathrm{n}-3$ & $48.6^{\mathrm{a}} \pm 4.7$ & $60.2^{\mathrm{b}} \pm 4.2$ & $55.9^{\mathrm{ab}} \pm 3.1$ & $57.1^{\mathrm{ab}} \pm 3.9$ \\
\hline $\mathrm{C} 22: 6 \mathrm{n}-3$ & $44.4^{\mathrm{a}} \pm 6.4$ & $56.0^{\mathrm{b}} \pm 3.9$ & $52.8^{\mathrm{ab}} \pm 2.7$ & $53.2^{\mathrm{ab}} \pm 3.3$ \\
\hline Total saturated & $222.7^{\mathrm{b}} \pm 5.0$ & $207.0^{\mathrm{a}} \pm 4.7$ & $209.0^{\mathrm{a}} \pm 5.2$ & $207.4^{\mathrm{a}} \pm 6.5$ \\
\hline Total monoenes & $400.8^{b} \pm 9.6$ & $380.9^{\mathrm{a}} \pm 2.1$ & $375.9^{\mathrm{a}} \pm 2.9$ & $372.8^{\mathrm{a}} \pm 4.6$ \\
\hline Total polyenes & $376.5^{\mathrm{a}} \pm 14.6$ & $412.1^{b} \pm 6.7$ & $415.1^{\mathrm{b}} \pm 8.1$ & $419.8^{\mathrm{b}} \pm 10.6$ \\
\hline Total n-3 & $171.3^{\mathrm{a}} \pm 13.1$ & $222.7^{b} \pm 9.7$ & $242.2^{\mathrm{bc}} \pm 8.2$ & $263.2^{\mathrm{c}} \pm 10.0$ \\
\hline Total n-6 & $193.1^{\mathrm{d}} \pm 0.5$ & $179.5^{\mathrm{c}} \pm 2.4$ & $158.6^{\mathrm{b}} \pm 2.1$ & $141.9^{\mathrm{a}} \pm 0.6$ \\
\hline Total n-9 & $285.6^{\mathrm{b}} \pm 6.8$ & $268.0^{\mathrm{a}} \pm 1.1$ & $264.7^{\mathrm{a}} \pm 1.6$ & $261.0^{\mathrm{a}} \pm 4.0$ \\
\hline $\mathrm{n} 3 / \mathrm{n} 6$ & $0.89^{\mathrm{a}} \pm 0.07$ & $1.24^{\mathrm{b}} \pm 0.05$ & $1.53^{\mathrm{c}} \pm 0.06$ & $1.85^{\mathrm{d}} \pm 0.07$ \\
\hline
\end{tabular}

Different superscript letters on the same line denotes significant differences $(P<0.05)$

a 100 SFO-group fed feed with sunflower oil (67 g/kg feed), 70SFO/30LO-group fed feed with sunflower and linseed oils (47 and $20 \mathrm{~g} / \mathrm{kg}$ feed), 30SFO/70LO-group fed feed with sunflower and linseed oils (20 and $47 \mathrm{~g} / \mathrm{kg}$ feed), 100LO-group fed feed with linseed oil $(67 \mathrm{~g} / \mathrm{kg}$ feed); for explanation of fatty acid groups see Table 1

from group 100LO was confirmed to be the lowest in comparison with the other groups. Lysozyme activity was lower in Japanese flounder, Paralichthys olivaceus, when there were deficits of long-chain fatty acids from the $n-3$ series in the feed (Wang et al. 2006). It has also been noted, however, that high quantities of ALA and/or low quantities of LA (with simultaneously low contents of EPA and DHA) (group 100LO) in the diet can increase dysfunction in immunological mechanisms in fish. In a study by Siwicki et al. (2006), in which the fish were fed commercial trout feed, the lysozyme activity in pikeperch blood was more than twice as high (nearly $50 \mathrm{mg} / \mathrm{l}$ ). Using VO in diets for fish might reduce the value of this parameter.

Feeding the pikeperch feeds with total $n-3 / n-6$ ratios of 0.36 (100SFO) and 2.15 (100LO) resulted in decreased metabolic and phagocytic activity of macrophages isolated from the spleen. Lowered proliferative response of lymphocytes to the mitogens ConA and LPS was also noted. Lowered macrophage activity and of lymphocytes responsible for cell-mediated immunity are caused by disturbances in the metabolism of these cells. The dietary oils determine the fatty acid profile of macrophages and could be connected with macrophage-dependent humoral and cellular immunity (Montero et al. 2003). It is possible that this is linked to decreased synthesis of the components of the immune system (eicosanoids, prostaglandin), which was also noted in Atlantic salmon and channel catfish, Ictalurus punctatus, fed feed with a high content of n-3 PUFA in relation to n-6 PUFA (Lin and Shiau 2007; Berge et al. 2009). Prostaglandin and thromboxane production by stimulated blood cells was reduced also in Atlantic salmon fed LO compared with those fed SFO (Bell et al. 1993).

Indeed, altering the $\mathrm{n} 3 / \mathrm{n} 6$ ratio within the range of 0.70-1.35 (groups 70SFO/30LO and 30SFO/70LO) in the feed substantially impacted the activity of macrophages and lymphocytes, which are important for proper non-specific defense mechanism function and for preventing diseases.

Body composition

The $n-3 / n-6$ ratio in all the pikeperch body parts analyzed increased proportionally to the content of 
Table 11 Fatty acid (FA) composition (g FA/kg total FA) of livers from pikeperch fed diets with different lipid sources (see Table 1) (mean $\pm \mathrm{SD} ; n=3$ )

\begin{tabular}{|c|c|c|c|c|}
\hline & \multicolumn{4}{|c|}{ Dietary treatments ${ }^{\mathrm{a}}$} \\
\hline & $100 \mathrm{SFO}$ & 70SFO/30LO & 30SFO/70LO & $100 \mathrm{LO}$ \\
\hline C14:0 & $34.9 \pm 0.3$ & $32.8 \pm 0.4$ & $35.3 \pm 3.4$ & $35.2 \pm 3.1$ \\
\hline $\mathrm{C} 16: 0$ & $169.2 \pm 8.8$ & $163.1 \pm 9.4$ & $173.6 \pm 12.3$ & $166.6 \pm 5.1$ \\
\hline $\mathrm{C} 18: 1$ cis 9 & $292.7 \pm 8.3$ & $275.8 \pm 15.1$ & $279.8 \pm 2.5$ & $270.9 \pm 2.8$ \\
\hline C18:2 n-6 & $243.7^{\mathrm{d}} \pm 4.6$ & $207.8^{c} \pm 10.6$ & $164.7^{\mathrm{b}} \pm 8.2$ & $138.5^{\mathrm{a}} \pm 6.5$ \\
\hline C18:3 n-3 & $42.9^{\mathrm{a}} \pm 0.1$ & $62.7^{\mathrm{b}} \pm 3.3$ & $99.6^{\mathrm{c}} \pm 5.4$ & $133.8^{\mathrm{d}} \pm 4.0$ \\
\hline C20:4 n-6 & $2.2 \pm 0.4$ & $2.6 \pm 0.5$ & $2.2 \pm 0.2$ & $2.6 \pm 0.1$ \\
\hline C20:5 n-3 & $20.0 \pm 4.3$ & $24.0 \pm 7.1$ & $18.4 \pm 2.2$ & $22.9 \pm 2.3$ \\
\hline $\mathrm{C} 22: 6 \mathrm{n}-3$ & $52.1 \pm 2.8$ & $65.6 \pm 13.5$ & $53.6 \pm 5.1$ & $54.5 \pm 7.3$ \\
\hline Total saturated & $225.4 \pm 9.0$ & $216.8 \pm 10.4$ & $230.2 \pm 15.7$ & $223.1 \pm 5.7$ \\
\hline Total monoenes & $419.8 \pm 13.3$ & $395.0 \pm 18.5$ & $405.9 \pm 5.1$ & $396.7 \pm 11.9$ \\
\hline Total polyenes & $367.2 \pm 9.8$ & $388.2 \pm 26.1$ & $363.9 \pm 20.3$ & $380.2 \pm 15.7$ \\
\hline Total n-3 & $123.4^{\mathrm{a}} \pm 8.9$ & $164.7^{\mathrm{b}} \pm 25.7$ & $183.3^{\mathrm{b}} \pm 11.5$ & $224.2^{\mathrm{c}} \pm 10.1$ \\
\hline Total n-6 & $239.0^{\mathrm{d}} \pm 4.4$ & $213.0^{\mathrm{c}} \pm 10.6$ & $168.3^{\mathrm{b}} \pm 8.3$ & $142.3^{\mathrm{a}} \pm 6.4$ \\
\hline Total n-9 & $301.9 \pm 3.1$ & $289.5 \pm 15.1$ & $293.1 \pm 2.7$ & $285.0 \pm 3.9$ \\
\hline $\mathrm{n} 3 / \mathrm{n} 6$ & $0.53^{\mathrm{a}} \pm 0.04$ & $0.78^{\mathrm{b}} \pm 0.14$ & $1.09^{c} \pm 0.02$ & $1.58^{\mathrm{d}} \pm 0.06$ \\
\hline
\end{tabular}

Different superscript letters on the same line denotes significant differences $(P<0.05)$

a 100 SFO-group fed feed with sunflower oil (67 g/kg feed), 70SFO/30LO-group fed feed with sunflower and linseed oils (47 and $20 \mathrm{~g} / \mathrm{kg}$ feed), 30SFO/70LO-group fed feed with sunflower and linseed oils (20 and $47 \mathrm{~g} / \mathrm{kg}$ feed), 100LO-group fed feed with linseed oil $(67 \mathrm{~g} / \mathrm{kg}$ feed); for explanation of fatty acid groups see Table 1

LA and ALA in the diet. Simultaneously, a different dependency was noted with regard to some of the other FA. High contents of oleic acid in the viscera confirmed the tendency for its accumulation as an energy source (Lanari et.al. 1999; Xu et al. 2001; Kowalska et al. 2010a). In turn, palmitic acid dominated in the fillets (184-203 g FA/ $\mathrm{kg} \mathrm{tFA}$ ), and not LA (101-133 g FA/kg tFA) or ALA (39-93 g $\mathrm{FA} / \mathrm{kg} \mathrm{tFA}$ ), as was the case in the experimental feeds. The quantity of DHA in the fillets was also substantially higher (167-176 g FA/kg tFA) than that in the feeds tested (43-50 g FA/kg tFA). This results from the function of these FA in the metabolism of phospholipids and their preferential accumulation in the fillets (Jobling 2001; Turchini et al. 2009). This is also why the feeds with different n-3/n-6 (0.36-2.15) ratios did not alter the levels of EPA or DHA in the pikeperch fillets. It is possible that this influenced not only assimilation but also the possibility of synthesizing DHA from EPA, which could imply a low content of EPA in the fillets (54-60 g FA/kg tFA). Undoubtedly, however, the low content of EPA in the fillets results mainly from the vegetable source of fat in the fish diet (Kowalska et al. 2010a, b; this study) (the quantity of EPA in the feeds used in the current study was just 33-37 g FA/kg tFA). The high content of ALA in the diets of the fish from groups 100LO and 30SFO/70LO resulted in the most advantageous $\mathrm{n} 3 / \mathrm{n} 6$ content in the fillets. Similarly, the diets fed fish from groups $100 \mathrm{SFO}$ and $70 \mathrm{SFO} / 30 \mathrm{LO}$ resulted in high contents of LA in the fillets as the LA is the type of FA that can be incorporated easily into all tissue lipids and stored in the lipid without modification (Xu and Kestemont 2002). Thus, because of the nutritional value of fish meat, the use of vegetable oils in which the dominant acid is LA should be limited (Turchini et al. 2009).

The process of FA synthesis in the liver can be affected by the dietary lipid composition. In perch, the elongation and desaturation enzymes are influenced by $n-3$ and n- 6 FA content in the diet (Xu and Kestemont 2002). Excessive dietary supplies of LA and ALA, which compete for desaturation enzymes, can disrupt the potential ability of transforming them, and consequently, this leads to the accumulation in the liver, deficits of ARA, EPA, and DHA 
in fish tissues, and reduced fish immunological function (Jankowska et al. 2003; Ruyter et al. 2006; Menoyo et al. 2007). Lowered immunological response in group 100LO could have been linked to similar contents of ALA and LA in the liver, the metabolism of which conditions the production of ARA, the precursors of eicosanoids linked to fish resistance. Although the increased amount of LA in comparison with that of ALA in the diets in the current experiment did not influence the quantity of ARA in the liver, a link was noted between the n-3/ $\mathrm{n}-6$ ratios of the diets and the synthesis of eicosanoids (Bell et al. 1991). It is important for diets to contain adequate quantities of precursors so as not to exclude the mutual transformation of EFA. With regard to pikeperch, the most advantageous of the experimental feeds tested was 30SFO/70LO, with ALA and LA in quantities of 175 and $193 \mathrm{~g} \mathrm{FA} / \mathrm{kg}$ tFA.

Very high quantities of LA in the livers in fish fed feed with sunflower oil (group 100 SFO) could have exacerbated the oxidation processes and lowered body immunity functions. Moreover, $\mathrm{Xu}$ and Kestemont (2002) showed that n-3 desaturations were inhibited by the SFO diet. Studies carried out in vitro suggest that linoleic acid oxidation products suppress lysozyme activity (Lin and Shiau 2007). The addition of antioxidants into plants oils could reduce these effects (Abramovic et al. 2007). Further studies concerning the use of antioxidants added into plant oil and their effect on usefulness in pike perch production should be investigated.

In summation, various $\mathrm{n} 3 / \mathrm{n} 6$ ratios in diets with LO and SFO did not influence fish growth. However, immunological indexes and the lowest quantities of LA in the fillets were obtained in the fish from group 30SFO/70LO. Using mixtures of VO allowed achieving balanced quantities of fatty acids and permitted avoiding the domination of single fatty acids, such as ALA or LA, which is detrimental to pikeperch. An $\mathrm{n} 3 / \mathrm{n} 6$ ratio in diets of 1.35 appeared to be the most advantageous when feeding juvenile pikeperch feeds that contain VO.

Acknowledgments The authors would like to thank feed manufacturer Aller-Aqua of Golub-Dobrzyń for their donation of the base feed used in the study. The study was conducted within the framework of the statutory research program of the Inland Fisheries Institute in Olsztyn (No. S007).
Open Access This article is distributed under the terms of the Creative Commons Attribution Noncommercial License which permits any noncommercial use, distribution, and reproduction in any medium, provided the original author(s) and source are credited.

\section{References}

Abramovic H, Butinar B, Nikoli V (2007) Changes occurring in phenolic content, tocopherol composition and oxidative stability of Camelina sativa oil during storage. Food Chem 104:903-909

AOAC (1975) Official methods of analysis of the association of official analytical chemists. Washington, 20044

Bell JG, McVicar AH, Park MT, Sargent JR (1991) High dietary linoleic acid affects the fatty acid compositions of individual phospholipids from tissues of Atlantic salmon (Salmo salar): association with stress susceptibility and cardiac lesion. J Nutr 121:1163-1172

Bell JG, Dick JR, McVicar AH, Sargent JR, Thompson KD (1993) Dietary sunflower, linseed and fish oils affect phospholipid fatty acid composition, development of cardiac lesions, phospholipase activity and eicosanoid production in Atlantic salmon (Salmo salar). Prostaglandins Leukot Essent Fatty Acids 49(3):665-673

Berge GM, Witten PE, Baeverfjord G, Vegusdal A, Wadsworth S, Ruyter B (2009) Diets with different $n-6 / n-3$ fatty acid ratio in diets for juvenile Atlantic salmon, effects on growth, body composition, bone development and eicosanoid production. Aquaculture 296:299-308

Chung S, Secombes SJ (1988) Analysis of events occurring within teleost macrophages during the respiratory burst. Biochem Physiol 89B:539-544

Cousin RJ (1985) Absorption, transport, and hepatic metabolism of copper and zinc: special reference to metallothionein and ceruloplasmin. Physiol Rev 65:238-309

Folch H, Less M, Stanley HA (1957) A simple method for isolation and purification of total lipids from animal tissues. J Biol Chem 226:49-497

Jankowska B, Zakęś Z, Żmijewski T, Szczepkowski M (2003) A comparison of selected quality features of the tissue and slaughter yield of wild and cultivated pikeperch, Sander lucioperca (L.). Eur Food Res Technol 217:401-405

Jobling M (2001) Feed composition and analysis. In: Houlihan $\mathrm{D}$, Boujard $\mathrm{T}$, Jobling $\mathrm{M}$ (eds) Food intake in fish. Blackwell Science Ltd, Oxford, pp 1-21

Karalazos V, Bendicksen EÅ, Dick JR, Bell JG (2007) Effect of dietary protein and fat level and rapeseed oil on growth and tissue fatty acid composition and metabolism in Atlantic salmon (Salmo salar L.) reared at low water temperatures. Aquacult Nutr 13:256-265

Karapanagiotidis IT, Bell MV, Little DC, Yakupitiyage A (2007) Replacement of dietary fish oils by alpha-linolenic acid-rich oils lowers omega 3 content in tilapia flesh. Lipids 42(6):547-559

Kowalska A, Zakęś Z, Jankowska B, Siwicki A (2010a) Impact of diets with vegetable oils on the growth, histological 
structure of internal organs, biochemical blood parameters, and proximate composition of pikeperch Sander $l u$ cioperca (L.). Aquaculture 301:69-77

Kowalska A, Zakęś Z, Jankowska B, Siwicki A (2010b) Substituting vegetable oil for fish oil in pikeperch diets: the impact on growth, internal organ histology, blood biochemical parameters, and proximate composition. Aquacult Nutr. doi:10.1111/j.1365-2095.2009.00744.x

Lanari D, Polil BM, Ballesstrazzi R, Lupi P, D’Agaro E, Mecatti M (1999) The effect of dietary fat and NFE level on growing European sea bass (Dicentrarchus labrax). Growth rate, body and fillet composition, carcass traits on nutrient retention efficiency. Aquaculture 179:351-364

Lin Y, Shiau S (2007) Effect of dietary blend of fish oil with corn oil on growth and non-specific immune response of grouper, Epinephelus malabaricus. Aquacult Nutr 13:137-144

Luchiari AC, de Moralis Freire FA, Koskela J, Pirhonen J (2006) Light intensity preference of juvenile pikeperch Sander lucioperca (L.). Aquacult Res 37:1572-1577

Menoyo D, Lopez-Bote CJ, Diez A, Obach A, Bautista JM (2007) Impact of n-3 fatty acid chain length and n-3/n-6 ratio in Atlantic salmon (Salmo salar) diets. Aquaculture 267:248-259

Montero D, Kalinowski T, Obach A, Robaina L, Tort L, Caballero MJ, Izquierdo MS (2003) Vegetable lipid sources for gilthead seabream (Sparus aurata): effects on fish health. Aquaculture 225:253-370

Mosmann T (1983) Rapidcolorimetric assay for cellular growth and survival: application to proliferation and cytotoxicity assays. J Immunol Methods 65:55-63

Nyina-Wamwiza L, Xu LX, Blanchard G, Kestemont P (2005) Effect of dietary protein, lipid and carbohydrate ratio on growth, feed efficiency and body composition of pikeperch Sander lucioperca fingerlings. Aquacult Res 36:486-492

Parpoura ACR, Alexis MN (2001) Effect of different dietary oils in sea bass (Dicentrarchus labrax) nutrition. Aquacult Int 9:463-476

Peisker K (1964) Rapid semi-micro method for methyl esters from triglycerides using chloroform, methanol, sulphuric acid. J Am Oil Chem Soc 11:87-90

Rice EW, Wagman E, Takenaka Y (1986) Ceruloplasmin assay in serum: standardization of ceruloplasmin activity in terms of international enzyme units. Diagn Lab 12:39-53

Ruyter B, Moya-Falcón C, Rosemlund G, Vegusdal A (2006) Fat content and morphology of liver and intestine of Atlantic salmon (Salmo salar): effects of temperature and soybean oil. Aquaculture 252:441-452

Schulz C, Knaus U, Wirth M, Rennert B (2005) Effects of varying dietary fatty acid profile on growth performance, fatty acid, body and tissue composition of juvenile pike perch (Sander lucioperca). Aquacult Nutr 11:403-413
Secombes CJ (1990) Isolation of salmonid macrophages and analysis of their killing activity. Tech Fish Immunol Methods 1:137-154

Siwicki AK, Anderson DP (1993) Immunostimulation in fish: Measuring the effects of stimulants by serological and immunological methods. US Fish Wildl Service-IFI 1-17

Siwicki AK, Dunier M (1990) Effect of levamisole on the lymphocyte and macrophage activity in carp (Cyprinus carpio). Annales de RecherchesVeterinaire 21:95-100

Siwicki KA, Zakęś Z, Trapkowska S, Kowalska A, Kazuń K, Głąbski E (2003) Selected hematological and biochemical parameters in pikeperch Sander lucioperca (L.) from intensive culture. Arch Pol Fish 11:17-22

Siwicki AK, Zakęś Z, Fuller JC Jr, Nissen S, Trapkowska S, Głąbski E, Kowalska A, Kazuń K, Terech-Majewska E (2006) Influence of $\beta$-hydroxy- $\beta$-methylbutyrate on nonspecific humoral defense mechanisms and protection against furunculosis in pikeperch (Sander lucioperca). Aquacult Res 37:127-131

Stubhaug I, Frøyland L, Torstensen BE (2005) $\beta$-oxidation capacity of red and white muscle and liver in Atlantic salmon (Salmo salar L.)-effects of increasing dietary levels of rapeseed oil (0-100) and olive oil (50\%) to replace capelin oil. Lipids 40:39-47

Torstensen BE, Bell JG, Rosenlund R, Henderson RJ, Graff IE, Tocher DR (2005) Tailoring of Atlantic salmon (Salmo salar L.) flrsh lipid composition and sensory quality by replacing fish oil with vegetable oil blend. J Agric Food Chem 53:10166-10178

Turchini GM, Torstensen BE, Ng WK (2009) Fish oil replacement in finfish nutrition. Rev Aquacult 1:10-57

Wang Z, Mai K, Liufu Z, Ma H, Xu W, Ai Q, Zhang W, Tan B, Wang X (2006) Effect of high dietary intake of vitamin E and n-3 HUFA on immune response and resistance to Edwardsiella tarda challenge in Japanese flounder (Paralichthys olivaceus, Temminck and Schlegel). Aquacult Res 37:681-692

Xu X, Kestemont P (2002) Lipid metabolism and FA composition in tissues of Eurasian perch Perca fluviatilis tissues as influenced by dietary fats. Lipids 37:297-304

Xu XL, Fontaine P, Mélard C, Kestemont P (2001) Effect of dietary fat levels on growth, feed efficiency and biochemical compositions of Eurasian perch Perca fluviatilis. Aquacult Int 9:437-449

Zakęś Z, Szczepkowski M (2004) Induction of out-of-season spawning of pikeperch, Sander lucioperca (L.). Aquacult Int 12:11-18

Zakęś Z, Demska-Zakęś K, Kowalska A, Csaba H, Jarmołowicz S (2010) Impact of diet supplemented with rapeseed, soy, and sunflower oils on growth rate and the histological Picture of the livers of juvenile pikeperch, Sander lucioperca (L.). Arch Pol Fish 18:67-75 